was published in volume XXXI of the reports of the Iowa Geological Survey. Professor Smith states that nearly ninety per cent of Iowa soil could be made more productive by the addition of limestone.

Iowa with her rich soil is one of the foremost agricultural states of the Union. Perhaps our pride in our soil resources causes us to underestimate the importance of our other natural resources. The rocks of the state are a great asset. Their value will be realized more and more as we assume to a greater extent than we have in the past our obligation to use in connection with the development of our industries and in other ways our own. natural resources rather than ship into the state from other states similar materials of no better quality than are to be found within our own borders.

\title{
IOWA COAL AREAS AND CHARACTERISTICS OF IOWA COAL
}

\section{JAMES H. LEeS}

I feel that the subject assigned to me for discussion is of very serious importance to the interests represented here, for no matter how we may designate the present stage of civilization-whether the age of steel or electricity or radio or even jazz-it still remains true that fuel is the basic resource of industry, and of the great primary sources of power and heat-coal, water-power, oil, natural gascoal is now and probably in our generation will remain well in the lead. If this is true it is well that every citizen should have an intelligent interest in this resource-its occurrence, its extent, its character and the best methods for its recovery and use.

A generalized time-scale to show those periods which are of special interest in this study may well be given here and is as follows:

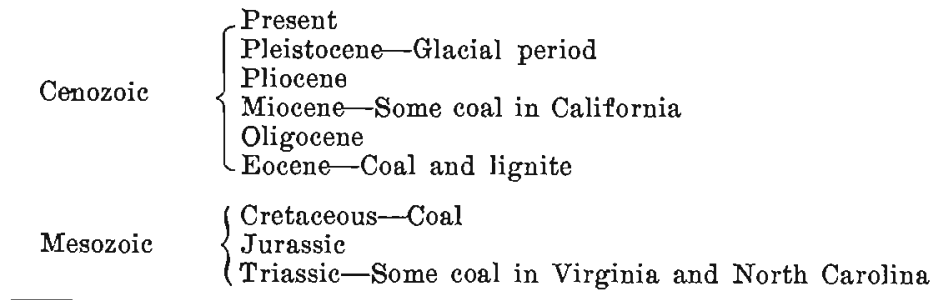

Professor E. C. Jeffrey of Harvard University in summarizing a recent paper on Conifers and the Coal Question says: "It is clear from the structural study of Tertiary coals and their contained woods that these coals can not have been formed in silu as is generally assumed, since the woods are those of land and even desert trees." "Tertiary coals in general - - are to be regarded as the result of water transportation and aqueous sedimentation." Science, N. S., vol. LXV. p. 357, April 8, 1927. 
Paleozoic $\quad\left\{\begin{array}{l}\text { Permian } \\ \text { Peannsylvanian-Coal } \\ \text { Mississippian-Some coal } \\ \text { Devonian } \\ \text { Silurian } \\ \text { Ordovician } \\ \text { Cambrian }\end{array}\right.$

Proterozoic

Archeozoic

The Iowa coal fields, in common with those of the Interior and Appalachian districts, belong to the Carboniferous, or as it is now coming to be known, the Pennsylvanian system of strata. Much of the coal of the Rocky Mountain province, on the other hand, is of Cretaceous age, while the lignites of the Gulf region and the Great Plains province and the coals of the Pacific coast are nearly all found in strata of Eocene age. Theoretically there is no direct relation between the geologic age of a coal bed and the character of the coal therein, but practically it is true that under normal conditions of deposition and preservation the older coals are of higher grade than are those of more recent age. This is illustrated in the gradation from the high grade bituminous coals of Pennsylvanian age in the eastern and central interior states through the softer bituminous and sub-bituminous coals of the Rocky Mountain Cretaceous to the Eocene lignites of the southern states and the northern Great Plains.

Then too the thickness of cover is an important factor in the hardness and general character of coals. For example the Pennsylvanian system of western Pennsylvania-the bituminous field-has a maximum thickness in the southwestern counties of 2600 feet and the upper division, which is the least productive but which furnishes the heaviest cover, is 800 feet thick above its one merchantable coal bed. The Pennsylvanian strata of the Illinois fields have a maximum thickness of 2000 feet, although the basal barren sandstones are in places 700 feet thick. Coal No. 6, the Herrin bed, the famous Franklin county coal, is reached in Franklin county at depths ranging from 200 to 700 feet. The Des Moines series, the productive coal measures of central and southeastern Iowa, are usually assigned a maximum thickness of 750 feet, but in most places the depth to the coal beds is much less than this, and few mines exceed 300 feet in depth. These figures naturally take no account of the thickness of strata which may have been removed by erosion in the immense 
interval which elapsed between the uplifting of the Pennsylvanian beds and the oncoming of the glaciers of the Ice Age, which covered these beds with a protective mantle of glacial drift. Then too the presence or absence of crustal movements and of volcanic activity involving coal beds is an important and in many cases a decisive factor in determining whether a given coal will eventually be anthracitic, bituminous or even sub-bituminous. The best known illustration of the effect of crustal, or dynamic, activity is the anthracite region of eastern Pennsylvania and the semi-bituminous fields of the Appalachian region. Several small fields of anthracite in the Rocky Mountain province and the Cascade Mountain region are due to igneous intrusions coupled in some measure with regional metamorphism. If it were not for these disturbances the coals now affected by them probably would be no better than those in neighboring regions-bituminous in eastern Pennsylvania, sub-bituminous in the Rocky Mountain province, and sub-bituminous or lignite in the Cascade region of Washington. The combination of a progressively thinning cover and of gradually diminished metamorphism from the Appalachian mountain region toward the Mississippi valley and the Great Plains forms an important if not a dominating factor in the progressive softening of the coals from the anthracites of eastern Pennsylvania to the bituminous coals of Iowa and Texas. There is no basic difference between the coals of different provinces. They were formed from similar materials and under approximately similar conditions. The Eastern province owes the thick strata of its Pennsylvanian system to the presence of a large and probably high land mass to east and northeast, from which large quantities of mud and sand were transported to the lagoons and marshes of the coastal regions. On the other hand the land area which drained into the inland sea covering the present Mississippi Valley-Isle Wisconsin and, probably, the Canadian Shield-furnished less wastage. perhaps becaúse of lower elevation, and hence thinner layers of rock material to enclose the newly formed coal beds. It seems likely too that conditions during coal formation were more stable in the Eastern province than farther west, in that the oscillations of sea and land were less frequent but of longer duration, iudging from the thickness of the coal beds, and probably of the sediments also.

The coincidence of heavy sedimentation and strong diastrophism in the East on the one hand and lighter sedimentation with practic- 
ally no diastrophism in the Mississippi Valley on the other hand is no mere accident but follows as the resultant of well established causes. The thick deposits were near. the continental margin, and such a combination was bound to result in crustal movement with crumpling, faulting, heating and all the changes that go on under the general process of metamorphism, with consequent compression and hardening of the coal and expulsion of much of the volatile substances. The Mississippi valley has, throughout its known geologic history, been more stable than the east and west coasts and less subjected to igneous or dynamic disturbances. Hence the strata here are more nearly in the condition and position they assumed when they consolidated.

I have dwelt at some length on these differing conditions of sedimentation, igneous intrusions and dynamic activity or diastrophism because they are fundamental in the formation and character of coal deposits and of the strata in which these coal beds are contained and because a knowledge of these conditions is invaluable in a geologic or economic study of the coals and their utilization. I should like now to consider in some detail the local conditions under which our Iowa coals were formed.

At the opening of Pennsylvanian time the land surface of the east-central part of the United States, say from Nova Scotia and southern New England westward to eastern Kansas, was low-lying but very irregular. In the Rocky Mountain and Pacific coast regions deep-sea conditions prevailed, so those areas are of no further concern to us. Some interesting evidence of the irregularity of the surface of the Mississippian strata has been revealed by drillings in Polk county. At Mitchellville the Mississippian limestones were reached about 760 feet above sea level, on the southeast edge of Des Moines 600 feet, in the western part of Des Moines 374 feet and at Commerce, west of the city, 300 feet above sea level. Another instance which recently came to my attention is shown in the new Chicago, Burlington and Quincy railroad well at Tracy, southeast of Des Moines. On the east bank of Des Moines river, opposite the village, the sandy limestones of St. Louis (upper Mississippian) age rise several feet above water level. In the well, which was drilled in the bottoms, only a few feet above river level, the Pennsylvanian shales were penetrated ninety-two feet before the St. Louis limestones were reached. There is here a difference in elevation of a hundred feet within two miles. Very similar conditions prevailed 
throughout the general region in which the coal beds were later to be formed.

The movements which had brought Mississippian deposition to a close and had raised above sea level large areas of land across the central-eastern part of the United States had developed a great geosyncline which extended from north-central Iowa southwestward as far as central Texas and perhaps farther in each direction. Probably similar synclines existed in the eastern part of the Mississippi valley and in the Appalachian region, where the eastern coal fields now exist.

Climatic conditions at the beginning of Pennsylvanian time became more favorable than ever before for the development of a very extensive and abundant vegetation. This was not a sudden development, for coal beds in Mississippian strata of the eastern states show the presence of similar conditions, although these were but the precursors of the exceptionally favorable situation of the Pennsylvanian. It does not seem necessary to assume, as was formerly done, the presence of a hot dense moist atmosphere through which the sun's rays had never penetrated and whose heavy gases were absorbed by the vegetation of the period. On the contrary the evidence points rather to possible aridity as well as to lower temperatures than were formerly assumed.

Under these general conditions then, the Pennsylvanian period began with the continental sea advancing up the Western Interior geosyncline from the southwest, just as it was advancing over other land areas farther east. On the low-lying marginal reaches between uplands and ocean a series of great coastal swamps was forming, similar to the Great Dismal swamp and the coastal marshes of Virginia and the Carolinas. Similar bogs or marshes no doubt developed over poorly drained areas remote from the sea, just as is true to-day, and so fresh water, brackish water, and salt water swamps existed simultaneously, each with its appropriate vegetation. This vegetation consisted of giant tree-ferns and horsetails, Lycopods such as Lepidodendron and Sigillaria, whose stems are now so often seen in coal and the associated rocks, and of an undergrowth containing smaller ferns and other lowly phases of plant life. The flowering plants and the modern types of trees had not yet appeared on the earth. Probably there was a growth of vegetation over the drier land areas, but as is the case with similar growths to-day such vegetation would normally leave no record of its existence. The 
elements of this marvelously developed flora, however, which lived in the swamps, as they died fell into the waters from which they had sprung and were there partly preserved. During the process of decay in the open air the carbon and hydrogen of wood unite with the oxygen of the air or of the wood and so form carbon dioxide and water and pass from our notice. But under water atmospheric oxygen is largely excluded, and the reactions are chiefly among the elements of the wood itself. Under these conditions marsh gas $\left(\mathrm{C} \mathrm{H}_{4}\right)$ is formed, with some carbon dioxide $\left(\mathrm{C} \mathrm{O}_{2}\right)$ and water $\left(\mathrm{H}_{2} \mathrm{O}\right)$. All of these processes would use up the carbon less rapidly than the other elements and so would result in the proportionate increase of carbon in the residue.

As generation after generation of the ancient plants lived, died, and fell to the floor of the swamp there was gradually accumulated an increasing layer of vegetable material which was constantly undergoing progressive changes which carried it further and further from its original state and into peaty and possibly lignitic stages. How fast this vegetal material accumulated is very difficult and perhaps impossible to estimate with any degree of accuracy. The abundance of vegetation and its rate of growth, the percentage which would be preserved, the prevailing climatic conditions and doubtless other factors would affect the problem. The estimate has been made that under conditions as we know them nearly 10,000 years would be required for the formation and preservation of a foot of vegetal material having a specific gravity of 1.4, about that of average coal.

In the course of time the interior sea reached Iowa. The marsh and bog types of vegetation grew and accumulated here as we have described the processes above and Iowa's coal resources began their formation. The statement has already been made that the surface over which the Pennsylvanian sea advanced was very irregular. Because of this fact the earliest deposits on a slowly sinking land area would be in the valleys and depressions and the burial of the hills and uplands would come later, perhaps much later. Some of the coal swamps which were formed in these depressions were limited by walls of limestone, and miners of the present day find these walls barring their further advance and marking the limits of the coal bed they are working.

Most of the basins and depressions in which the Iowa coal swamps formed were rather limited in extent, and so the accumulations of 
vegetäble matter which later became consolidated into coal are not very large, most of them being only a few hundred or at most a few. thousand acres in size. These beds are mostly lenticular in vertical section, being much thicker near the center than on the margins, where they usually feather out and finally disappear. One noteworthy exception to this rule, however, is the bed known as the Centerville or Mystic seam. This bed, although it has an average thickness of only about two and a half feet, and has a rather wide vertical range, still is very uniform in its character and appearance, as well as in its thickness, and is estimated to underlie in workable condition about 1500 square miles in Appanoose and Wayne counties in Iowa and several neighboring counties of Missouri.

It must not be supposed that the interior sea progressed uniformly and uninterruptedly from southwest to northeast, or that conditions remained the same throughout Pennsylvanian time. On the contrary there were many oscillations of the land and since much of the area under discussion was near the critical level of crustal movement, the sea level, it was inevitable that because of these movements the coast line should frequently swing back and forth over the marginal areas on either side the strand. These oscillations resulted in equivalent alternations of deposits--when a given area was at the proper position above sea level vegetation was accumulating, but when this area was under the sea it and its contained bed of vegetal matter became covered by a layer of sand or mud or perhaps limy ooze, depending on local conditions. These materials in due time were consolidated into sandstone or shale or limestone and also by their weight compressed the underlying bed of vegetal matter until it assumed the characters of lignite or the various grades of bitumous coal. The thickness of each deposit depended, of course, on the length of time it was accumulating, in other words the interval between successive effective oscillations, the rate at which material was contributed, the amount of condensation caused by compression or drying or chemical changes and doubtless by other factors. The estimate has been made that a vigorous growth of vegetation would yield annually about a ton of dried matter per acre. If the annual yield for a thousand years were all preserved, except for the natural loss by escaping gases, and were duly compressed it would yield less than an inch and a half of coal. In spite of this slow growth some Iowa coal beds are known to have thicknesses of eight to ten feet, and one bed with a measured thickness of 
thirteen and one-half feet and a reported thickness at another point of sixteen feet has been found in Marion county. Most of the beds which are worked, however, are four to five feet thick on an average. From these thicknesses they range down to mere films between layers of shale or other rock. I know of no estimate of the total thickness of coal in the Iowa measures, and indeed such an estimate would be difficult to make and of little value when it was made owing to the limited extent of the beds, their differing thickness, and the fact that the beds of a given locality are not all actually superimposed, but may be widely scattered. It may be said with assurance, however, that the coal beds form only a small percentage of the total thickness of the Iowa coal measures, as is true in other states. The purity of the accumulating material-viewed from the standpoint of the vegetation - would depend on the amount of waste mattermud and sand-which was washed in from surrounding uplands or brought in by streams. If such material were nearly or entirely absent the deposit might, after the necessary processes, become a high grade coal while conversely a large amount of this detrital material would cause the deposit to be bony coal or perhaps only a carbonaceous shale. It must be kept in mind that this feature is quite apart from the presence of that mineral matter which is an original and essential constituent of the plant and which on combustion would become ash and sulphur. This will be discussed somewhat in connection with the character of Iowa coals.

- The rock makers of the Pennsylvanian-conglomerates, sandstones, shales and limestones-form much the greater bulk of the strata, even though they are not quite so important economically. The source of these materials has been mentioned above, and it may be said in addition that the conglomerates would accumulate close to the land, where the streams and the currents would first begin to drop their loads, while the sands and clays would be carried and dropped progressively farther off shore, where the waters were quieter and the currents had less and less carrying power. The limestones would form in still, clear, though not necessarily very deep waters, but nevertheless under more typically marine conditions. With a knowledge of these varying conditions under which different strata form we are able to recreate to some extent a picture of the circumstances under which the earlier beds of the Pennsylvanian system of Iowa were laid down. These beds are known as the Des Moines series, and at present they cover southwestern Iowa 
and extend as far north as Onawa and Humboldt while their eastern margin may be defined roughly as along a line drawn between Iowa Falls and Keokuk. Undoubtedly the Des Moines seas had a much wider extent as outliers of their deposits are known at many places as far north and east as Iowa City, and Maquoketa, and a large mass with workable coal beds is present between Muscatine and Davenport. Probably at their widest extent the Iowa and Illinois arms of the epi-continental sea were united over eastern Iowa and western Illinois. Most of these outliers, however, contain no coal beds or only very thin ones, indicating that conditions in those localities or at those times were not favorable to the accumulation of vegetal material as coal. Formerly the strata exposed or otherwise known to exist at a number of places in western Iowa, such as Logan and Atlantic, were thought to belong to a higher series than the Des Moines, but more recent study points to their Des Moines age. It is a peculiar fact and one of large economic interest that very little coal has been found in these strata west of Guthrie Center and Jefferson-or in other words, west of the eastern margin of the overlying strata. A few evidences of the presence of coal have been found, as at Missouri Valley and Denison, but here again conditions for extensive and recurrent coal formation do not seem to have been present.

In southwestern Iowa the Des Moines series is overlain by a group of beds known as the Missouri series. This consists of many alternating beds of limestones and shales of marine origin together with two beds of coal, which resemble the Mystic bed in their uniformity of thickness and character and their rather wide distribution. The upper or Nyman coal is too thin to be of economic importance, as it is not more than a foot thick. The lower bed, the Nodaway coal, is about sixteen inches thick and has been mined in Montgomery and Page and western Adams and Taylor counties. It comes to the surface in the latter two counties but is known from borings as far west as Nebraska City.

Overlying all the older formations of northwestern and westcentral Iowa are the sandstones of the Dakota stage and the limestones and shales of the Colorado stage, both belonging to the Cretaceous system. The Cretaceous of northwestern Iowa carries some lignite, but the beds are too thin and of too poor quality to be of economic value. The sandstones extend as far east as Jefferson and Guthrie Center and as far south as Cass and Adams counties, with 
outliers beyond, but their chief importance lies in the fact that they cover up the Missouri and Des Moines beds and so render these formations more difficult of access.

Mr. M. R. Campbell in 1913 estimated the original area of the known productive coal field of Iowa as 12,560 square miles, with an estimated tonnage of $29,168,000,000$ short tons. Similar estimates had been made previously by the United States Geological Survey in which the total area of the coal-bearing formations of Iowa was usually given as about 20,000 square miles of which about 13,000 might be considered potentially productive. I do not know on just what basis of extent and thickness of coul beds these estimates have been made except that Mr. Campbell states that 14 inches is taken as the minimum thickness. That would just take in the Nodaway field, and Mr. Campbell's map indicates that as one of the workable fields.

In connection with this study I have made the following computations. The area of Iowa underlain by beds of Des Moines age is 24,250 square miles. I suppose that all of this area may be considered as legitimate prey for the promoter if not for the prospector. The area of Des Moines beds which are not covered by Missouri or Cretaceous strata is about 11,250 square miles, or $7,200,000$ acres, and it is a rather remarkable coincidence, as I have suggested, that the region which is overlain by these later beds is the least productive part of the Des Moines series. If now we consider all of this area to be coal-bearing, which probably is an exaggeration, and if we assume an average thickness of workable coal of four feet, which probably is a sufficiently liberal allowance and which will give a content of 4000 tons per acre, we shall have a total original volume of $28,800,000,000$ torns. The total possible area underlain by the Nodaway coal of southwestern Iowa is about 1500 square miles or 960,000 acres, according to recent studies of that region. The maximum thickness which we may assign to this coal is 1.2 foot, which would give a yield of $1,150,000,000$ tons. The total coal supplies from the two series of strata, then, would be $29,950,000,000$ tons. Now on the one hand future explorations may extend the known areas of workable coal beyond the western limits which I have suggested, and further requirements may necessitate the use of thinner and deeper beds than those now being mined. These factors if realized will increase the available supply. On the other hand it is practically certain that hundreds of square miles within the pro- 
ductive territory are absolutely barren and that other hundreds contain only beds that are too thin to be of great service under any economic conditions. Then too there are bodies of coal of workable extent and thickness which have too poor roof or too much water to be available under present or reasonably calculable future mining possibilities. These factors will decrease the available supply by an unknown amount, but by one which will, I fear, at least counterbalance the favorable factors.

With regard to the possible depth of mining in Iowa it may safely be said that there is no danger of the economical limit being reached for the simple reason that coal absolutely does not exist in Iowa at the great depths which are entirely feasible with modern mining and hoisting machinery. The deepest mines in the state are in Dallas county near Waukee and are 373 feet and 417 feet deep. The Des Moines and Missouri strata are thickest in the southwestern part of the state, and here the records of the wells at Glenwood and Bedford place the base of the Des Moines series-the lowest possible horizon for finding coal-at 1235 feet and 1340 feet respectively below curb, probably as great depths as these strata reach anywhere in the state. In 1913 the Assumption Coal Co. was hoisting coal in Christian county, Illinois, from a depth of 1004 feet. A good many shafts in the anthracite field of Pennsylvania are more than 1000 leet deep. An English colliery is hoisting coal from a two- to sixfoot bed at a depth of 3900 feet, and another is mining a two-foot bed 2460 feet below the surface. These figures indicate the possibilities in future Iowa mines if necessity arises.

Up to the end of 1925 Iowa coal mines had produced $264,300,000$ tons, of which practically $100,000,000$ tons had been mined since 1910. If we assume, as is usually done, that half a ton was left in the mine for each ton that was removed, that means a total exhaustion of $396,450,000$ tons or a little less than 1.4 per cent of the total supply. If we estimate the annual exhaustion as $10,000,000$ tons, the average for the past fifteen years, we shall see that the supply is still good for 2950 years. Even if it seems best to reduce the estimate by fifty. per cent, the supply is sufficient to remove worry to the distant future-as human life goes. The Nodaway field, at the present rate of exhaustion, about 35,000 tons a year, should last for 35,000 years.

The earliest recorded production of coal in Iowa was given in the U. S. Census for 1840 as 400 tons. In 1848 the production reached 
10,000 tons; In 1867 it was 150,000 tons; in 1876 the output was $1,250,000$, and by 1899 it had reached $5,000,000$. The largest production was $8,965,000$ tons in 1918 , although the greatest spot value was reached in 1920 , when the output was valued at $\$ 30,800,000$. Since 1920 the production has been less than during most of the earlier years of the present century. This decline in production probably is to be assigned in part to adverse financial conditions in the state, in part, to increasing use of outside coals by Iowa people and in part to the mine labor situation. Approximately 15,000,000 tons of coal are used in Iowa every year, and of this amount nearly two-thirds is shipped in from other states. The reasons for this condition can be best discussed in connection with the character of Iowa coal. Discussions of the financial and labor situations really have no place in this paper.

The Nodaway coal is mined by the longwall system, by which the coal is undercut and breaks down by its own weight and that of the superincumbent strata. Powder is not used to a great extent, and hence the coal is not shot to pieces so badly as by other methods. A few machines have been used for undercutting, but most of the work is done with picks. Similar methods are used in the Centerville bed of Appanoose and Wayne counties, the former of which divides with Polk county the distinction of using more than half of the mining machines in operation in Iowa. In most of the other Iowa mines, the shortwall or room and pillar method is used, and the coal is "shot from the solid." That is, it is drilled and blasted with powder or other explosive, after a cut has been made along the side of the room. This method produces a great deal of small coal which must be sold as steam coal, bit it seems to be preferred by the miners. However, machine mining and the longwall system are used in some mines. About eighty mining machines are in use in the state. Shortwall mining necessitates lèaving about one-third of the coal in the ground, while longwall methods permit nearly complete extraction.

Now what are the outstanding characteristics of Iowa coals? All of them are relatively soft, some of them more than relatively. All are high-ash-and-sulphur coals, with the percentage of volatile matter nearly as high as that of the fixed carbon-within about 6 per cent on the average. They do not stand air storage very well as the sulphur oxidizes and the coal breaks down. On the other hand a casual inspection of a large number of analyses of Illinois coals, for 
example, will show that those coals do not contain many more heat units on the average than do Iowa coals. Neither do the analyses show a vast difference in chemical composition. Why then are Illinois and eastern coals supplanting Iowa coals in Iowa markets? I believe that the answer to this question lies as much in the physical character of the coals as in their chemical analysis and their B.t.u.s. Because of their cover and the other conditions mentioned earlier in this paper the Iowa coals have not been compressed into so hard layers as have the eastern coals. All coals show more or less alternating bright and dull laminae, of which the latter are somewhat softer than the former and contain more mother coal or mineral charcoal. This mother coal is softer than the brighter coal, and a coal which contains much of it will not have the hardness and the ability to stand up under rough handling and other treatment that brighter more solid and uniform coals possess. Doctor Savage of the Illinois Geological Survey has suggested that the mother coal and the dull laminae were formed when the water level of the swamp was a little lower than usual and decay of the vegetation went on for a time in the air. When the water level rose the layers formed under water would make the bright bands. Iowa coals contain a good deal of mother coal and dull laminae. So do Illinois coals, but the eastern coals are more uniformly bright.

Owing to these physical characters, and perhaps to others, when Iowa coal is fed into the ordinary house furnace it is decomposed rather quickly and easily: Much of the volatile matter and some of the carbon are driven off before they can be heated to the ignition point. Hence a large amount of smoke and soot and gas goes into the chimney, where it is valueless for heating purposes. Hence the hue and ery about dirty Iowa coal. Hence the swing over to harder coals with less ash and sulphur and the use of ten million tons of foreign coal in Iowa and.only five million tons of domestic coal.

As between the different Iowa fields it may be said that the Centerville bed is somewhat softer than the other coals but that it stores well if it is kept from undue moisture. In such conditions it loses weight somewhat, showing that it is giving up its own moisture. On account of its softness and of its block structure it requires careful handling and shielding from moisture to avoid excessive breakage and slacking. Therefore it should be shipped in closed cars. The Nodaway coal is in general similar to the Centerville, and as it is mined by similar methods it needs similar treatment. The coals of 
the other parts of the Des Moines series, in what may be called the shortwall or shooting fields, do not differ greatly in physical characters. Some are harder and some are softer; some contain less ash and sulphur, and some contain more. In a few cases the volatiles exceed the fixed carbon, as in one analysis which follows. But one can not draw any areal limits and put the coals of different qualities therein. The good coals are where you find them; the poorer ones hold the rest of the field.

In 1917 I made a statement in the Iowa Magazine which I may summarize as follows :

$\begin{array}{lccr} & \text { Ash, per cent } & \text { B. t. u. } & \text { Cost } \\ \text { Average Iowa coal } & 11.63 & 10,657 & \\ \text { Average Illinois coal } & 8.80 & 11,148 & \\ \text { Difference, favor Illinois } & 2.83 & 491 & \\ \text { Four Des Moines coals } & 10 . & 11,400 & \$ 4.50 \\ \text { Franklin Co., Ill., coal } & 9.04 & 12,276 & 7.00 \\ \text { Difference, favor Illinois } & 1 . & 876 \text { or } 7 \% & 2.50\end{array}$

We may let these statements stand as representing, with changed cost values, the present situation for domestic fuels. However, I should like to give here a few analyses of Iowa coals and of foreign coals that are competing in our markets for the domestic trade. The prices given are for retail delivery in Des Moines. The analyses are of coal "as received," and most of them are from car samples. The last one is not strictly comparable as it is a computed average of analyses of sixteen coals which were collected from mine faces by the writer. Still it will serve in a general comparison.

\begin{tabular}{|c|c|c|c|c|c|}
\hline \multicolumn{6}{|c|}{ Analyses of Lump Coals } \\
\hline & A & $\mathrm{B}$ & $\mathrm{C}$ & D & $\mathbf{E}$ \\
\hline Moisture & 1.72 & 1.32 & 3.75 & 4.65 & 6.80 \\
\hline Volatile matter & 10.46 & 38.31 & 36.75 & 36.85 & 39.06 \\
\hline Fixed carbon & 79.50 & 56.67 & 55.30 & 52.65 & 50.28 \\
\hline Ash & 8.32 & 3.70 & 4.20 & 10.85 & 10.66 \\
\hline Sulphur & 2.49 & 0.62 & 0.70 & 1.58 & 3.22 \\
\hline B.t.u. & 13,876 & 14,270 & 14,110 & 12,500 & 12,880 \\
\hline Cost per ton & $\$ 13.00$ & $\$ 13.00$ & $\$ 12.00$ & $\$ 10.00$ & $\$ 10.00$ \\
\hline & $\mathbf{F}$ & G & $\mathrm{H}$ & $\mathrm{I}$ & $\mathrm{J}$ \\
\hline Moisture & 12.19 & $\mathbf{1 7 . 1 3}$ & 10.78 & 19.11 & 15.07 \\
\hline Volatile matter & 39.48 & 35.44 & 41.56 & 30.45 & 34.09 \\
\hline Fixed carbon & 37.28 & 40.36 & 36.75 & 38.86 & 39.21 \\
\hline Ash & 10.71 & 7.07 & 10.91 & 11.58 & 11.63 \\
\hline Sulphur & 4.56 & 4.00 & 4.43 & 4.26 & 4.52 \\
\hline B. t. u. & 10,446 & 10,932 & 11,253 & 10,233 & 10.657 \\
\hline Cost per ton & $\$ 7.00$ & $\$ 7.50$ & $\$ 7.00$ & & \\
\hline
\end{tabular}

\footnotetext{
A. Arkansas semianthracite, Hartshorn seam, Johnson county.

B. West Virginia semianthracite.

C. Eastern Kentucky "Hot Spot," Perry county.
} 
D. Western Kentucky, bed No. 12, Muhlenberg county.

E. Franklin county, Illinois, John A. Logan Coal Co., bed No. 6.

F. Great Western Coal Co., Des Moines, Orillia mine. Average of several face samples. Data from Mr. J. H. Durrell, Mgr.

G. Centerville, Iowa, Mystic mine No. 3.

H. Norwood-White Coal Co., Mine No. 8, Herrold, Polk county, Iowa. Face sample. This analysis is rather unusual in that the volatile matter is greater in amount than the fixed carbon.

I. Nodaway coal, Campbell Coal Co., New Market, Taylor county, Iowa.

J. "Average coal." Average of sixteen selected samples.

The facts and conditions outlined above apply with even more force to the power users of the state. On the one hand much more attention has been paid to scientific and efficient combustion under power boilers than in domestic furnaces, but on the other hand steam sizes of Iowa coals are of much poorer quality than domestic sizes. Mr. Marsh in his recent book on combustion in the power plant says that Iowa coals have proved the undoing of more stokers, probably, than any other fuels. However, it seems to me that he gives us rather the worst of it when he says that "in this staite coal containing 16 per cent of ash is really choice fuel and even 26 per cent ash coal is only 'poor.' Bad Iowa coal contains 35 to 40 per cent of ash." I believe that the analyses of lump coal given above and those of steam sizes given below will bear out this contention.

\begin{tabular}{lcccccc}
\multicolumn{7}{c}{ Analyses of Steam Coals } \\
Moisture & $\mathrm{A}$ & $\mathrm{B}$ & $\mathrm{C}$ & $\mathrm{D}$ & $\mathrm{E}$ & $\mathrm{F}$ \\
Volatile matter & Dry & 16.99 & 1.6 .64 & 10.12 & 11.09 & 13.66 \\
Fixed carbon & 37.7 & 30.45 & 29.38 & 31.60 & 29.65 & 30.35 \\
Ash & 48.6 & 35.93 & 31.80 & 34.58 & 34.29 & 38.00 \\
Sulphur & 13.7 & 16.63 & 22.18 & 23.70 & 24.97 & 17.99 \\
B. t. u. & 4.0 & 4.11 & 4.38 & 5.39 & 6.72 & 4.24 \\
Cost per ton & 12,510 & 9,082 & 8,478 & 8,884 & 8,167 & 9,266 \\
& $\$ 3.75$ & $\$ 3.97$ & $\$ 2.97$ & $\$ 2.63$ & $\$ 2.48$ & $\$ 2.74$ \\
Moisture & $\mathrm{G}$ & $\mathrm{H}$ & $\mathrm{I}$ & $\mathrm{J}$ & $\mathrm{K}$ & \\
Volrtile matter & 13.66 & 6.53 & 5.98 & 6.58 & 9.30 & \\
Fixed carbon & 30.42 & 37.47 & 38.71 & 37.51 & 33.20 & \\
Ash & 30.44 & 46.12 & 46.14 & 45.03 & 51.30 & \\
Sulphur & 28.38 & 9.88 & 9.17 & 10.88 & 6.20 & \\
B. t. u. & 6.20 & 3.06 & 3.17 & 3.31 & 2.80 & \\
Cost per ton & 7,333 & 11,962 & 12,143 & 11,823 & 12,995 & \\
& $\$ 2.65$ & $\$ 6.52$ & $\$ 5.74$ & $\$ 5.09$ & $\$ 6.00$ &
\end{tabular}

A. Scandia Coal Co., mines in Dallas county, Iowa. Analysis by U. S. Bureau of Mines. Based on 20 cars 6 by 2 inch egg delivered to Fort Des Moines. Moisture as received was 13.2 per cent. B. t. u. 10,860. Data from Mr. K. G. Carney.

B. and C. Scandia Coal Co. B, crushed mine run; C, steam coal. Analyses are "as fired" and moisture is about 2 per cent higher than as received.

D. Flint Coal Co., Des Moines. Nut mixed as delivered to Roosevelt High School.

E. Des Moines Coal Co., Des Moines. Nut mixed as delivered to North High School. 
F. Economy Coal Co., Des Moines. Nut mixed as delivered to East High School.

G. Des Moines Coal Co., Des Moines. Nut mixed as delivered to Lincoln High School.

Analyses B to G are by Mr. J. A. Lysaght, chemist for Des Moines City Railway. B and C, courtesy Mr. Carney; D to G, courtesy Mr. W. R. Spry, custodian of school buildings.

H. I. J. John A. Logan Coal Co., Chicago. Mines in Franklin county, Illinois. $H$ is egg coal, $I$ is No. 2 nut, $J$ is $1 \frac{1}{2}$ inch screenings. All analyses as received. Furnished by Mr. K. G. Carney.

K. Western Kentucky steam coal. Car load lot, three-fourths inch screenings.

I am not going to discuss the burning of steam coal, as Mr. Marsh can do that more practically than I can. I should like to suggest, however, the desirability of continued study of the questions related to that problem, by both coal users and coal producers. The question of reducing the ash content of steam coals, for example, by dry cleaning and by washing merits most careful consideration. A recent paper in the Proceedings of the Australasian Institute of Mining and Metallurgy on "The Burden of High-Ash Coal" classifies ash as inherent, which cannot be reduced, and extraneous, which may be removed by careful mining and cleaning. Both forms impose a burden which mounts to immense figures, as for instance in steel making in the United States where each per cent of increase in ash content adds 33 cents to the cost of producing a ton of pig iron, a total added cost of $\$ 13,000,000$ annually. A brief paper by Doctor Olin and Mr. Troeltzsch, published recently by the Iowa Geological Survey, gives the results of crushing and flotation tests on several Iowa coals and offers encouragement for further study and experimentation in this direction. In this paper the authors classify sulphur in coal as organic, which cannot be removed, and inorganic, mainly pyrite, a good deal of which is removable and which it should be the object of all concerned to remove to the greatest possible extent.

In summary we may state that: Coal was formed in swamps, many of which were, of great extent. The thicker the cover the harder the coal.

Crustal movements and metamorphism help to make harder coal. Iowa coal is of Pennsylvanian age, as are the eastern coals.

The coal beds alternate with other strata owing to changes in level of sea and land and changes in deposition.

The known productive coal areas of Iowa amount to about 12,750 square miles, of which 11,250 square miles are in the Des Moines 
series and 1500 miles in the Missouri series. The possible tonnage of this area is $29,950,000,000$.

No coals exist in Iowa beyond the economical limit of mining.

Only a little more than. one per cent of the possible supply has been used so far. At this rate there is coal enough to last nearly 3000 years.

The Centerville and Nodaway coals are mined Iongwall, without shooting. Most other coal is shot and is mined shortwall.

Because of thinner cover and less metamorphism Iowa coals are softer than eastern coals. Also they contain more alternations of softer dull laminae and harder bright laminae, which adds to their softness.

Iowa coals are dirtier and make more smoke than most other coals used in this state but with careful use will yield good results.

The following references were consulted:

Coal Deposits of Iowa, Henry Hinds. Fuel Values of Iowa Coals, F. A. Wilder. Analyses of Iowa Coals, A. W. Hixson and James H. Lees: Iowa Geological Survey, vol. XIX.

Analyses of Iowa Coals, A. W. Hixson: Iowa Geological Survey, vol. XXIV.

Distribution of Ash and Sulfur in Iowa Coals, H. L. Olin and J. R. Troeltzsch: Iowa Geological Survey, vol. XXXI.

Missouri Séries of Pennsylvanian System in Southwestern Iowa, J. L. Tilton: Iowa Geological Survey, vol. XXIX.

Report of Iowa Mine Inspectors, 1924 and 1925.

Purchase and Sale of Illinois Coal on Specification, S. W. Parr: Illinois Geological Survey, Bull. No. 29.

Coal Resources of District VII, F. H. Kay: Illinois Geological Survey, Coal Mining Investigations, Bull. 11.

Twenty-second Annual Report, Part III, Coal: U. S. Geological Survey, 19001901.

Mineral Resources of the United States, 1910: U. S. Geological Survey.

Analyses of Coals in the United States: U. S. Bureau of Mines, Bull. 22.

Analyses of Iowa Coals: U. S. Bureau of Mines, Technical Paper 269.

Coal Resources of the World, vol. II: XII International Geological Congress, 1913.

Geology, vol. II, Chamberlin and Salisbury.

The Burden of High-Ash Coal, K. Butler: Australasian Institute of Mining and Metallurgy, No. 63.

Combustion in the Power Plant, T. A. Marsh.

Conditions Under which Vegetable Matter in Mlinois Coal Beds Accumulated, T. E. Savage: Journal of Geology, vol. XXII, p. 754.

They Weren't Pyramids After All, James H. Lees: Iowa Magazine, AprilMay, 1917.

Random Notes on Coal and its Mining. George H. Ashley: Coal Age, vol. 31, p. 805.

Text-Book of Geology, Pirsson and Schuchert, 2d ed., pt. II, chaps. xxvii-xxix. 